\title{
PERSEPSI TAMU TERHADAP PELAYANAN HOTEL NAYA GAWANA RESORT AND SPA
}

\author{
Desak Komang Selly Sutrisna Dewi \\ Jurusan Pendidikan Ekonomi \\ Universitas Pendidikan Ganesha \\ Singaraja, Indonesia \\ e-mail: desakselly90@gmail.com
}

\begin{abstract}
Abstrak
Tujuan penelitian ini adalah untuk mengetahui persepsi tamu terhadap pelayanan Hotel Naya Gawana Resort and Spa. Jenis penelitian ini adalah deskriptif. Populasi penelitian ini adalah tamu Hotel Naya Gawana Resort and Spa. Sampel ditentukan sebanyak 100 orang yang diambil dengan menggunakan teknik incidental sampling. Data dikumpulkan dengan kuesioner dan dianalisis secara deskriptif. Hasil penelitian menunjukkan bahwa persepsi tamu terhadap pelayanan Hotel Naya Gawana Resort and Spa ditinjau dari dimensi motivasi dikategorikan sangat setuju dengan total skor sebesar 1.802 yang berada antara $1.680-2.000$. Persepsi tamu terhadap pelayanan Hotel Naya Gawana Resort and Spa ditinjau dari dimensi harapan dikategorikan sangat setuju dengan total skor sebesar 2.734 yang berada antara $2.520-3.000$. Persepsi tamu terhadap pelayanan Hotel Naya Gawana Resort and Spa ditinjau dari dimensi lingkungan dikategorikan sangat setuju dengan total skor sebesar 4.090 yang berada antara 3.780 - 4.500. Persepsi tamu terhadap pelayanan Hotel Naya Gawana Resort and Spa ditinjau dari dimensi kedekatan dikategorikan sangat setuju dengan total skor sebesar 2.183 yang berada antara $2.100-2.500$. Persepsi tamu terhadap pelayanan Hotel Naya Gawana Resort and Spa ditinjau dari dimensi suasana hati dikategorikan sangat setuju dengan total skor sebesar 1.337 yang berada antara $1.260-1.500$.
\end{abstract}

Kata kunci: Persepsi Tamu, Pelayanan Hotel

\begin{abstract}
The purpose of this research is to know the guest perception on service at Naya Gawana Resort And Spa Hotel. The type of this research is descriptive. The population of this research is the guest at Naya Gawana Resort And Spa Hotel. The sample was determined as many as 100 people which are taken using the technique of incidental sampling. The data collected by questionnaires and are analyzed descriptively. The results showed that 1) guest perception on service at Naya Gawana Resort And Spa Hotel in terms of the dimensions of motivation are categorized very agree with total score of 1,802 which is between $1,680-2,000$. 2) guest perception on service At Naya Gawana Resort And Spa Hotel in terms of the dimensions of hope categorized very agree with total score of 2,734 which is between 2,520 - 3,000. 3) guest perception on service at Naya Gawana Resort And Spa Hotel in terms of the environmental dimensions categorized very agree with total score of 4,090 which is between 3,780 - 4,500. 4) guest perception on service at Naya Gawana Resort And Spa Hotel in terms of proximity dimension categorized very agree with total score of 2,183 which is between 2,100 - 2,500. 5) guest perception on service at Naya Gawana Resort And Spa Hotel in terms of mood dimensions categorized very agree with total score of 1,337 which is between $1,260-1,500$.
\end{abstract}

Keyword : Guest Perception, Service Hotel 


\section{PENDAHULUAN}

Bali merupakan salah satu daerah tujuan wisata di Indonesia yang memiliki keunikan budaya, adat istiadat, dan kaya akan kesenian daerah, serta masyarakatnya yang dikenal ramah. Hal inilah yang membuat para wisatawan domestik maupun mancanegara yang berkunjung ke Bali merasa nyaman tinggal di Bali.

$$
\text { Dengan adanya kunjungan }
$$

wisatawan yang berkunjung di Bali maka diperlukan sarana prasaran penunjang misalnya akomodasi restauran serta pelayanan lain yang menunjang wisatawan tertarik ke Bali. Sulastiyono (2002:5) menyatakan, Hotel adalah suatu perusahaan yang dikelola oleh pemiliknya dengan menyediakan pelayanan makanan, minuman dan fasilitas kamar untuk tidur kepada orang-orang yang sedang melakukan perjalanan dan mampu membayar dengan jumlah yang wajar sesuai dengan pelayanan yang diterima tanpa adanya perjanjian khusus.

Hotel Naya Gawana Resort And Spa mempunyai salah satu hotel di kawasan Bali Barat tepatnya di Desa Pejarakan, Kecamatan Gerokgak, Kabupaten Buleleng. Hotel Naya Gawana Resort And Spa merupakan salah satu hotel bintang empat yang memiliki 70 orang karyawan dan 37 kamar dengan 4 tipe kamar, yaitu 4 Standar Room, 17 Bay View Swite, 12 Lumbung Swite, dan 4 Mangrove Swite disediakan kepada para wisatawan domestik maupun manca negara. Salah satu keistimewaan hotel ini adalah karena keindahan pantai pasir putih dan hutan mangrove.

Hal utama yang dikedepankan oleh hotel adalah bagaimana cara memberikan pelayanan yang baik sehingga mampu memberikan rasa kepuasan tersendiri bagi pelanggannya. Ada banyak cara yang dilakukan untuk menciptakan kepuasan atau kesenangan bagi para konsumennya, misalnya untuk menyediakan berbagai fasilitas dan hiburan yang disesuaikan dengan kebutuhan para tamunya, seperti fasilitas kamar yang lengkap, restaurant yang menyediakan beragam hidangan makanan dan minuman, fasilitas kolam renang, fasilitas ruang pertemuan, dan fasilitas lainnya. Para tamu yang menginap di hotel tidak hanya menggunakan hotel sebagai tempat menginap atau istirahat semata, namun mereka juga memanfaatkan fasilitas lain yang disediakan oleh hotel misalnya sarana olahraga (fitness), swimming pool dan lain-lain. Banyaknya tamu yang datang berbeda-beda maka tujuan yang dimanfaatkan fasilitas hotel oleh tamu kepuasan yang dirasakan juga berbedabeda sesuai yang dipersepsi berdasar apa yang dirasakan. Menurut Rakhmat (2007) "persepsi adalah pengalaman tentang objek, peristiwa atau hubungan-hubungan yang diperoleh dengan menyimpulkan informasi dan menafsirkan pesan". Selanjutnya untuk meningkatkan jumlah kunjungan hotel, pihak hotel ingin memberikan pelayanan yang maksimal bagi tamu hotel sesuai dengan persepsi persepsi tamu terhadap pelayanan hotel. Menurut Rakhmat (2007) dimensi persepsi terdiri dari pengetahuan, motivasi, harapan, lingkungan, kedekatan, dan suasana hati.

Sesungguhnya, segala persepsi atau penilaian yang dilakukan oleh para tamu bisa dikatakan sangat berperan besar terhadap keberlangsungan hotel tersebut. Persepsi tamu tentang kelebihan dan kekurangan yang dimiliki oleh hotel akan berdampak pada kepuasannya secara tidak langsung. Persepsi dapat digunakan sebagai media promosi bagi hotel. Ketika seorang tamu memberikan persepsi yang positif terhadap suatu hotel maka tamu akan menyampaikan/ merekomendasikan kepada para kerabatnya yang berkeinginan untuk menginap di hotel tersebut, atau sebaliknya.

Begitu pentingnya suatu persepsi atau penilaian dari seorang tamu, sehingga banyak hotel-hotel berbintang atau hotel kelas melati yang menyediakan "guest comment", baik itu melalui suatu form maupun comment secara online. 
Tujuan dilakukannya guest comment adalah untuk mendapatkan suatu cerminan bagaimana keadaan hotel Naya Gawana Resort And Spa dan kinerja mereka di mata para tamunya. Selain itu, melalui guest comment ini, pihak hotel akan mengetahui bagaimana tingkat kesenangan atau kepuasan dari tamunya. Menurut Desiderato (dalam Rakhmat, 2007:51) "persepsi adalah pengalaman tentang objek, peristiwa atau hubunganhubungan yang diperoleh dengan menyimpulkan informasi dan menafsirkan pesan". Menurut Sarwono (2002:94) "persepsi adalah proses pencarian informasi untuk dipahami". Alat untuk memperoleh informasi tersebut adalah penginderaan (penglihatan, pendengaran, perabadan sebagainya). Sebaliknya alat untuk memahaminya adalah kesadaran atau kognisi. Poerwadarminta (2003:880) menyatakan "persepsi adalah tanggapan (penerimaan) langsung dari sesuatu atau proses seseorang mengetahui beberapa hal melalui panca inderanya". Slameto (2003: 102) menyatakan bahwa "persepsi adalah proses yang menyangkut masuknya pesan atau informasi ke dalam otak manusia". Seseorang dalam menjalin hubungan dengan lingkungannya, maka seseorang tersebut akan membentuk persepsi terhadap lingkungan itu sendiri. Menurut Walgito (2002) bahwa "persepsi merupakan suatu proses yang didahului oleh proses penginderaan yaitu proses diterimanya stimulus oleh individu melalui alat indera atau juga disebut proses sensoris". Berdasarkan stimulus yang diterima oleh seseorang selanjutnya akan membentuk persepsi seseorang. Menurut Robbins \& Judge (2009) "persepsi adalah proses individu mengatur dan menginterpretasikan kesan-kesan sensoris mereka guna memberikan arti bagi lingkungan mereka". Berdasarkan beberapa pengertian persepsi di atas, maka dapat disimpulkan bahwa persepsi adalah suatu proses penerimaan, penilaian, pengorganisasian, dan penginterprestasian rangsangan (stimulus) oleh seseorang atau sekelompok orang terhadap objek, peristiwa, stimulus, atau hubungan-hubungan yang diperoleh dengan melibatkan pengalaman untuk menyimpulkan dan menafsirkan pesan.

$$
\text { Proses terbentuknya persepsi }
$$

dimulai dari diterimanya stimulus suatu objek dan kemudian seseorang akan merespon stimulus tersebut. Adapun objek yang dipersepsi sangat banyak, objek tersebut dapat berupa sesuatu yang ada di sekitar manusia seperti benda, budaya, manusia, dan lingkungan. Karena sangat banyaknya objek yang dapat dipersepsi, maka pada umumnya objek persepsi dibedakan menjadi dua kelompok, menurut Walgito (2002) objek persepsi dapat dibedakan atas objek yang nonmanusia dan manusia. Objek persepsi yang berwujud manusia disebut person perception atau juga social perception. Sedangkan persepsi yang berobjekkan non-manusia disebut nonsocial perception atau juga disebut sebagai things perception. Objek yang dipersepsi baik manusia maupun non-manusia ini memiliki persamaan dan perbedaan. Persamaannya yaitu apabila manusia dipandang sebagai objek benda yang terikat pada waktu dan tempat. Sedangkan perbedaannya yaitu jika yang dipersepsi adalah manusia, maka objek persepsi mempunyai aspek yang sama dengan yang mempersepsi, akan tetapi jika objek yang dipersepsi non-manusia, maka tidak akan terdapat aspek yang sama.

Ada banyak faktor yang mempengaruhi persepsi, menurut Walgito (2004) bahwa dalam proses persepsi terkandung komponen kognitif dan konatif. Komponen kognitif adalah komponen yang berkaitan dengan pengetahuan, pandangan dan keyakinan terhadap objek yang diperkenalkan. Komponen kognitif diilustrasikan melalui pengetahuan misalnya seseorang beranggapan bahwa dengan menabung sejak dini akan membantu dalam mencukupi kebutuhannya di masa yang akan datang. Sedangkan komponen konatif adalah perilaku yang sudah sampai pada tahap individu melakukan sesuatu (perbuatan) terhadap objek. Dalam komponen konatif dapat dicontohkan seseorang akan membersihkan kamarnya yang kotor supaya bersih dan nyaman ditempati. 
Menurut Rakhmat (2006) faktor-faktor yang dapat mempengaruhi persepsi seseorang, yaitu faktor fungsional, faktor struktural, dan faktor situasional.

Faktor fungsional adalah faktor yang berasal dari dalam dirinya sendiri. Adapun faktor fungsional yang mempengaruhi persepsi seseorang adalah motivasi dan harapan. Motivasi merupakan unsur dari proses pengembangan diri yang akan mempengaruhi persepsi antar pribadi. Jadi persepsi seseorang terhadap suatu objek tergantung pada suatu keadaan atau proses yang bersifat membangun. Motivasi adalah daya pendorong yang mengakibatkan seorang anggota organisasi mau dan rela untuk mengerahkan kemampuan, dalam bentuk keahlian atau keterampilan, tenaga dan waktunya untuk menyelenggarakan berbagai kegiatan yang menjadi tanggung jawabnya dan menunaikan kewajibannya, dalam rangka pencapaian tujuan dan berbagai sasaran organisasi yang telah ditentukan sebelumnya (Siagian, 1986 : 132).Dimensi motivasi, motivasi mengandung 3 komponen penting yang saling berkaitan erat, yaitu : pertama kebutuhan, kebutuhan timbul dari dalam individu apabila merasa adanya kekurangan dalam dirinya (ada ketidakseimbangan antara apa yang dimiliki dengan apa yang menurut persepsi individu harus dimiliki). Kedua dorongan,Untuk mengatasi ketidakseimbangan tersebut, dalam diri individu akan timbul dorongan berupa usaha pemenuhan kebutuhan secara terarah. Ketiga tujuan, pencapaian tujuan berarti mengembangkan keseimbangan dalam diri seseorang/ individu.

Harapan yaitu keinginan individu baik dalam jangka pendek maupun jangka panjang yang ingin dicapai seseorang. Persepsi seseorang terbentuk salah satunya karena adanya harapan yang harus dipenuhi. Misalnya seorang pelajar dari desa berharap bisa menempuh pendidikan tinggi di bidang kependidikan supaya bisa mengajar dan mendidik masyarakat di desanya, sehingga belajar di perguruan tinggi dalam bidang pendidikan merupakan suatu harapan yang ingin diraihnya supaya bisa mengembangkan pendidikan di desanya.
Harapan adalah kemampuan untuk merencanakan jalan keluar dalam mencapai tujuan meskipun terdapat berbagai rintangan. Menurut Hasibuan (2005:117) indikator-indikator tentang harapan para karyawan sebagai berikut, kondisi hotel yang baik, perasaan ikut terlibat, pendisiplinan yang bijaksana, penghargaan penuh atas penyelesaian pekerjaan, loyalitas pimpinan terhadap karyawan. Faktor stuktural adalah faktor yang berasal dari luar individu seperti lingkungan dan konteks kedekatan. Pengalaman seseorang atau individu yang dilalui berdasarkan serangkaian peristiwa yang pernah dihadapi dapat mempengaruhi kecermatan persepsi. Faktor situasional berkaitan dengan bahasa non verbal. Adapun faktor situasional yang mempengaruhi persepsi adalah, Suasana hati yaitu keadaan emosi individu yang mempengaruhi perilaku sesorang ketika menerima suatu informasi. Suasana hati dapat mempengaruhi persepsi tergantung suasana hati individu dalam keadaan gembira atau sedih. Hal ini akan menyebabkan persepsi individu dengan individu yang lain akan berbeda. Suasana hati adalah keadaan emosi seseorang yang dipengaruhi oleh suatu objek atau peristiwa dan akan diwujudkan dalam bentuk sikap. Bila emosi dikategorikan menjadi dua kelompok positif dan negatif, maka akan menjadi keadaan suasana hati karena sekarang emosi dipandang secara lebih umum dan bukan satu emosi tertentu. Pendidikan merupakan suatu harapan yang ingin diraihnya supaya bisa mengembangkan pendidikan di desanya. Harapan adalah kemampuan untuk merencanakan jalan keluar dalam mencapai tujuan meskipun terdapat berbagai rintangan. Hasibuan (2005:117) mengemukakan indikator-indikator tentang harapan para karyawan sebagai berikut, kondisi hotel yang baik, perasaan ikut terlibat, pendisiplinan yang bijaksana, penghargaan penuh atas penyelesaian pekerjaan, loyalitas pimpinan terhadap karyawan. Faktor stuktural adalah faktor yang berasal dari luar individu seperti lingkungan dan konteks kedekatan. Pengalaman seseorang atau individu yang 
dilalui berdasarkan serangkaian peristiwa yang pernah dihadapi dapat mempengaruhi kecermatan persepsi. Faktor situasional berkaitan dengan bahasa non verbal. Adapun faktor situasional yang mempengaruhi persepsi adalah, Suasana hati yaitu keadaan emosi individu yang mempengaruhi perilaku sesorang ketika menerima suatu informasi. Suasana hati dapat mempengaruhi persepsi tergantung suasana hati individu dalam keadaan gembira atau sedih. Hal ini akan menyebabkan persepsi individu dengan individu yang lain akan berbeda. Suasana hati adalah keadaan emosi seseorang yang dipengaruhi oleh suatu objek atau peristiwa dan akan diwujudkan dalam bentuk sikap. Bila emosi dikategorikan menjadi dua kelompok yaitu positif dan negatif, maka akan menjadi keadaan suasana hati. Berdasarkan pendahuluan diatas maka tujuan dari penelitian ini adalah untuk mengetahui persepsi tamu terhadap pelayanan Hotel naya Gawana Resort and Spa.

\section{METODE}

Hotel Naya Gawana Resort And Spa yang beralamat di Desa Pejarakan, Kecamatan Gerokgak, Kabupaten Buleleng.

Jenis data yang digunakan dalam penelitian ini adalah data kualitatif. Data kualitatif dalam penelitian ini yakni persepsi tamu terhadap pelayanan Hotel Naya Gawana Resort and Spa. Sumber data yang digunakan dalam penelitian ini adalah data primer. Data primer dalam penelitian ini yaitu hasil kuesioner yang diisi oleh tamu yang berkunjung ke Hotel Naya Gawana Resort and Spa.

Dalam melakukan penelitian, peneliti menggunakan metode kuesioner.
Kuesioner digunakan untuk memperoleh data tentang persepsi tamu terhadap pelayanan Hotel Naya Gawana Resort and Spa kepada 100 orang tamu yang berkunjung yang dijadikan sampel penelitian dari seluruh populasi tamu yang berkunjung ke Hotel Naya Gawana Resort and Spa.

Teknik pengambilan sampel menggunakan teknik incidental sampling. Sedangkan kuesioner menggunakan skala likert yang terdiri dari 5 (lima) pilihan jawaban kepada responden, yaitu (1) Sangat Tidak Setuju (STS), (2) Tidak Setuju (TS), (3) Kurang Setuju (KS), (4) Setuju (S), dan (5) Sangat Setuju (SS).

Teknik analisis data yang digunakan dalam penelitian ini adalah analisis deskriptif. analisis deskriptif digunakan untuk mendeskripsikan persepsi tamu terhadap pelayanan Hotel Naya Gawana Resort and Spa.

Menurut Irianto (2004), untuk memperoleh skala interval persepsi dilakukan langkah-langkah sebagai berikut. Menentukan skor terendah dan skor tertinggi dari keseluruhan alternatif jawaban.

$$
\text { skor }_{\max }=\begin{aligned}
& \text { nilai maksimal } \\
& \text { pertanyaan } \\
& \text { skor } \\
& \text { responden }
\end{aligned}=\begin{gathered}
\text { jumlah } \\
\text { nilai minimal } \\
\begin{array}{l}
\text { ertanyaan } \\
\text { responden }
\end{array}
\end{gathered}
$$

Menentukan interval persepsi tamu terhadap pelayanan Hotel Naya Gawana Resort and Spa

$$
\text { Interval }=\frac{\text { ghor tertingi-shor terendah }}{\text { kategori }}
$$

Dari langkah-langkah di atas maka kriteria persepsi ditinjau dari dimensi motivasi dapat dilihat pada tabel 1 .

Tabel 1. Kriteria total skor persepsi tamu terhadap pelayanan Hotel Naya Gawana Resort and Spa ditinjau dari dimensi motivasi

\begin{tabular}{cc}
\hline Rentang Skor & Kategori \\
\hline $1.680-2.000$ & Sangat Setuju \\
$1.359-1.679$ & Setuju \\
$1.038-1.358$ & Kurang Setuju \\
$717-1.037$ & Tidak Setuju \\
$396-716$ & Sangat Tidak Setuju \\
\hline
\end{tabular}


Kriteria persepsi dengan total skor 396 - 716, maka persepsi wisatawa terhadap pelayanan Hotel Naya Gawana Resort and Spa ditinjau dari dimensi motivasi dinyatakan sangat tidak setuju. Kriteria persepsi dengan total skor 717 1.037 dinyatakan tidak setuju. Kriteria persepsi dengan total skor 1.038 - 1.358 dinyatakan kurang setuju. Kriteria persepsi dengan total skor 1.359 - 1.679 dinyatakan setuju, dan jika kriteria persepsi dengan total skor 1.680 - 2.000, maka persepsi tamu terhadap pelayanan Hotel Naya Gawana Resort and Spa ditinjau dari dimensi motivasi dinyatakan sangat setuju.

Kriteria persepsi ditinjau dari dimensi harapan dapat dilihat pada tabel 2 .

Tabel 2. Kriteria total skor persepsi tamu terhadap pelayanan Hotel Naya Gawana Resort and Spa ditinjau dari dimensi harapan

\begin{tabular}{cl}
\hline Rentang Skor & \multicolumn{1}{c}{ Kategori } \\
\hline $2.520-3.000$ & Sangat Setuju \\
$2.039-2.519$ & Setuju \\
$1.558-2.038$ & Kurang Setuju \\
$1.077-1.557$ & Tidak Setuju \\
$596-1.076$ & Sangat Tidak Setuju \\
\hline
\end{tabular}

Kriteria persepsi dengan total skor 596 - 1.076, maka persepsi tamu terhadap pelayanan Hotel Naya Gawana Resort and Spa ditinjau dari dimensi harapan dinyatakan sangat tidak setuju. Kriteria persepsi dengan total skor 1.077 - 1.557 dinyatakan tidak setuju. Kriteria persepsi dengan total skor 1.558 - 2.038 dinyatakan kurang setuju. Kriteria persepsi dengan total skor 2.039 - 2.519 dinyatakan setuju, dan jika kriteria persepsi dengan total skor 2.520 - 3.000, maka persepsi tamu terhadap pelayanan Hotel Naya Gawana Resort and Spa ditinjau dari dimensi harapan dinyatakan sangat setuju.

Kriteria persepsi ditinjau dari dimensi lingkungan dapat dilihat pada tabel 3.

Tabel 3. Kriteria total skor persepsi persepsi tamu terhadap pelayanan Hotel Naya Gawana Resort and Spa ditinjau dari dimensi lingkungan

\begin{tabular}{cl}
\hline Rentang Skor & \multicolumn{1}{c}{ Kategori } \\
\hline $3.780-4.500$ & Sangat Setuju \\
$3.059-3.779$ & Setuju \\
$2.338-3.058$ & Kurang Setuju \\
$1.617-2.337$ & Tidak Setuju \\
$896-1.616$ & Sangat Tidak Setuju \\
\hline
\end{tabular}

Kriteria persepsi dengan total skor 896 - 1.616, maka persepsi persepsi tamu terhadap pelayanan Hotel Naya Gawana Resort and Spa ditinjau dari dimensi lingkungan dinyatakan sangat tidak setuju. Kriteria persepsi dengan total skor 1.617 2.337 dinyatakan tidak setuju. Kriteria persepsi dengan total skor 2.338 - 3.058 dinyatakan kurang setuju. Kriteria persepsi dengan total skor 3.059 - 3.779 dinyatakan setuju, dan jika kriteria persepsi dengan total skor 3.780 - 4.500, maka persepsi tamu terhadap pelayanan Hotel Naya Gawana Resort and Spa ditinjau dari dimensi kedekatan dinyatakan sangat setuju.

Kriteria persepsi ditinjau dari dimensi kedekatan dapat dilihat pada tabel 4 . 
Tabel 4. Kriteria total skor persepsi persepsi tamu terhadap pelayanan Hotel Naya Gawana Resort and Spa ditinjau dari dimensi kedekatan

\begin{tabular}{cl}
\hline Rentang Skor & \multicolumn{1}{c}{ Kategori } \\
\hline $2.100-2.500$ & Sangat Setuju \\
$1.699-2.099$ & Setuju \\
$1.298-1.698$ & Kurang Setuju \\
$897-1.297$ & Tidak Setuju \\
$496-896$ & Sangat Tidak Setuju \\
\hline
\end{tabular}

Kriteria persepsi dengan total skor 496 - 896, maka persepsi tamu terhadap pelayanan Hotel Naya Gawana Resort and Spa ditinjau dari dimensi kedekatan dinyatakan sangat tidak setuju. Kriteria persepsi dengan total skor $897-1.297$ dinyatakan tidak setuju. Kriteria persepsi dengan total skor 1.298 - 1.698 dinyatakan kurang setuju. Kriteria persepsi dengan total skor 1.699 - 2.099 dinyatakan setuju, dan jika kriteria persepsi dengan total skor 2.100 - 2.500, maka persepsi tamu terhadap pelayanan Hotel Naya Gawana Resort and Spa ditinjau dari dimensi kedekatan dinyatakan sangat setuju.

Kriteria persepsi ditinjau dari dimensi suasana hati dapat dilihat pada tabel 5 .

Tabel 5. Kriteria total skor persepsi persepsi tamu terhadap pelayanan Hotel Naya Gawana Resort and Spa ditinjau dari dimensi suasana hati

\begin{tabular}{cl}
\hline Rentang Skor & \multicolumn{1}{c}{ Kategori } \\
\hline $1.260-1.500$ & Sangat Setuju \\
$1.019-1.259$ & Setuju \\
$778-1.018$ & Kurang Setuju \\
$537-777$ & Tidak Setuju \\
$296-536$ & Sangat Tidak Setuju \\
\hline
\end{tabular}

Kriteria persepsi dengan total skor 296 - 536, maka persepsi tamu terhadap pelayanan Hotel Naya Gawana Resort and Spa ditinjau dari dimensi suasana hati dinyatakan sangat tidak setuju. Kriteria persepsi dengan total skor 537 - 777 dinyatakan tidak setuju. Kriteria persepsi dengan total skor 778 - 1.018 dinyatakan kurang setuju. Kriteria persepsi dengan total skor 1.019 - 1.259 dinyatakan setuju, dan jika kriteria persepsi dengan total skor
1.260 - 1.500, maka persepsi tamu terhadap pelayanan Hotel Naya Gawana Resort and Spa ditinjau dari dimensi suasana hati dinyatakan sangat setuju.

\section{HASIL DAN PEMBAHASAN Hasil \\ Persepsi tamu terhadap pelayanan Hotel Naya Gawana Resort and Spa ditinjau dari dimensi motivasi menunjukkan hasil sebagai berikut.}

Tabel 6. Hasil analisis data persepsi tamu terhadap pelayanan Hotel Naya Gawana Resort and Spa ditinjau dari dimensi motivasi

\begin{tabular}{|c|c|c|c|}
\hline Dimensi & Skor & Skala Interval & Kategori \\
\hline motivasi & 1.802 & $1.680-2.000$ & $\begin{array}{l}\text { Sangat } \\
\text { Setuju }\end{array}$ \\
\hline Total & 1.802 & $1.680-2.000$ & $\begin{array}{l}\text { Sangat } \\
\text { Setuju }\end{array}$ \\
\hline
\end{tabular}

Hasil penelitian menunjukkan bahwa dimensi motivasi diperoleh skor 1.802. skor 1.802 sesuai dengan hasil perhitungan skala interval persepsi berada pada skala interval $1.680-2.000$, sehingga persepsi dikatakan sangat setuju, Hal ini berarti tamu sangat setuju bahwa mereka termotivasi untuk 
menginap di hotel ini karena pelayanan hotel kepada tamu sudah memuaskan. Setiap tamu yang datang, karyawan hotel bersedia mengantarkan tamu ke kamar hotel, dan peralatan mandi yang disediakan hotel sudah lengkap dan bersih.

Persepsi tamu terhadap pelayanan Hotel Naya Gawana Resort and Spa ditinjau dari dimensi harapan menunjukkan hasil sebagai berikut.

Tabel 7. Hasil analisis data persepsi tamu terhadap pelayanan Hotel Naya Gawana Resort and Spa ditinjau dari dimensi harapan

\begin{tabular}{|c|c|c|c|}
\hline Dimensi & Skor & $\begin{array}{c}\text { Skala } \\
\text { Interval }\end{array}$ & Kategori \\
\hline Harapan & 2.734 & $2.520-3.000$ & $\begin{array}{l}\text { Sangat } \\
\text { Setuiu }\end{array}$ \\
\hline Total & 2.734 & $2.520-3.000$ & $\begin{array}{l}\text { Sangat } \\
\text { Setuju }\end{array}$ \\
\hline
\end{tabular}

Hasil penelitian menunjukkan bahwa dimensi harapan diperoleh skor sebesar 2.734. skor 2.734 sesuai dengan hasil perhitungan skala interval persepsi berada pada skala interval 2.520 - 3.000, sehingga persepsi dikatakan sangat setuju, Hal ini berarti tamu sangat setuju bahwa pelayanan yang diinginkan oleh para tamu sudah sesuai harapan seperti pelayanan pada saat melaksanakan registrasi untuk tamu dan mengalokasikan kamar sesuai dengan permintaan, pelayanan tentang tata cara menata kamar/ruangan, dan pelayanan saat menyediakan makanan dan minuman untuk para tamunya sudah dilakukan dengan baik. Disamping itu juga, tamu berpendapat bahwa karyawan hotel sudah berpenampilan rapi dan sopan dalam melayani tamu sehingga mereka dapat merekomendasikan kepada temannya untuk menginap di hotel tersebut.

Persepsi tamu terhadap pelayanan Hotel Naya Gawana Resort and Spa ditinjau dari dimensi lingkungan menunjukkan hasil sebagai berikut.

Tabel 8. Hasil analisis data persepsi tamu terhadap pelayanan Hotel Naya Gawana Resort and Spa ditinjau dari dimensi lingkungan

\begin{tabular}{|c|c|c|c|}
\hline Dimensi & Skor & Skala Interval & Kategori \\
\hline lingkungan & 4.090 & $3.780-4.500$ & $\begin{array}{l}\text { Sangat } \\
\text { Setuju }\end{array}$ \\
\hline Total & 4.090 & $3.780-4.500$ & $\begin{array}{l}\text { Sangat } \\
\text { Setuju }\end{array}$ \\
\hline
\end{tabular}

Hasil penelitian menunjukkan bahwa dimensi lingkungan diperoleh skor sebesar 4.090. skor 4.090 dengan hasil perhitungan skala interval persepsi berada pada skala interval 3.780 - 4.500, sehingga persepsi dikatakan sangat setuju, Hal ini berarti tamu sangat setuju bahwa lokasi hotel sangat mudah ditemukan dan memiliki lingkungan yang bersih yang didukung dengan pemandangan yang indah seperti pantai pasir putih di sekitar hotel, dan penataan ruang bangunan hotel yang menarik, sehingga tamu merasa nyaman berada di hotel ini.

Persepsi tamu terhadap pelayanan Hotel Naya Gawana Resort and Spa ditinjau dari dimensi kedekatan menunjukkan hasil sebagai berikut. 
Tabel 9. Hasil analisis data persepsi tamu terhadap pelayanan Hotel Naya Gawana Resort and Spa ditinjau dari dimensi kedekatan

\begin{tabular}{|c|c|c|c|}
\hline Dimensi & Skor & Skala Interval & Kategori \\
\hline Kedekatan & 2.183 & $2.100-2.500$ & $\begin{array}{l}\text { Sangat } \\
\text { Setuju }\end{array}$ \\
\hline Total & 2.183 & $2.100-2.500$ & $\begin{array}{l}\text { Sangat } \\
\text { Setuju }\end{array}$ \\
\hline
\end{tabular}

Hasil penelitian menunjukkan bahwa dimensi kedekatan diperoleh skor sebesar 2.183. skor 2.183 dengan hasil perhitungan skala interval persepsi berada pada skala interval 2.100 - 2.500, sehingga persepsi dikatakan sangat setuju, Hal ini berarti tamu sangat setuju bahwa hotel selalu merespon keluhan para tamu dengan baik. Karyawan hotel sudah mampu berkomunikasi dengan baik, komunikasi yang dilakukan karyawan hotel dengan tamu sudah komunikatif dengan tata bahasa yang sudah bagus, sehingga tamu merasa nyaman menginap di hotel ini.

Persepsi tamu terhadap pelayanan Hotel Naya Gawana Resort and Spa ditinjau dari dimensi suasana hati menunjukkan hasil sebagai berikut.

Tabel 10. Hasil analisis data persepsi tamu terhadap pelayanan Hotel Naya Gawana Resort and Spa ditinjau dari dimensi suasana hati

\begin{tabular}{cccc}
\hline Dimensi & Skor & Skala Interval & Kategori \\
\hline $\begin{array}{c}\text { Suasana } \\
\text { hati } \\
\text { Total }\end{array}$ & 1.337 & $1.260-1.500$ & $\begin{array}{c}\text { Sangat } \\
\text { Setuju } \\
\text { Sangat } \\
\text { Setuju }\end{array}$ \\
\hline
\end{tabular}

Hasil penelitian menunjukkan bahwa dimensi suasana hati diperoleh skor sebesar 1.337. skor 1.337 dengan hasil perhitungan skala interval persepsi berada pada skala interval $1.260-1.500$, sehingga persepsi dikatakan sangat setuju, Hal ini berarti tamu sangat setuju bahwa mereka merasakan pelayanan pada hotel ini sudah memuaskan sehingga tamu sangat senang dan nyaman selama menginap dihotel ini. Di samping itu juga kualitas makanan yang disediakan hotel sudah sesuai dengan harga dan selera tamu hotel. Restaurant yang bersih yang berada disekitaran pinggiran pantai pasir putih memberikan rasa damai dan nyaman untuk para tamu hotel. baik, komunikasi yang dilakukan karyawan hotel dengan tamu sudah komunikatif dengan tata bahasa yang sudah bagus, sehingga tamu merasa nyaman menginap di hotel ini

\section{Pembahasan}

Berdasarkan hasil penelitian menunjukkan bahwa persepsi tamu terhadap pelayanan Hotel Naya Gawana Resort and Spa ditinjau dari dimensi motivasi menunjukkan kategori sangat setuju. Adapun hasil penelitian di peroleh skor dimensi motivasi sebesar 1.802 yang berada pada skala interval $1.680-2.000$ yang menunjukkan bahwa persepsi dikategorikan sangat setuju. Hal ini berarti tamu setuju bahwa pelayanan terhadap tamu sudah memuaskan. Karyawan hotel bersedia mengantarkan tamu ke kamar hotel, dan peralatan mandi yang disediakan hotel sudah lengkap dan bersih. Karyawan hotel juga bersikap ramah dan sopan. Karyawan hotel selalu memberikan informasi dan memberi salam dan senyuman kepada tamu hotel yang berkunjung. Pelayanan hotel sangat mempengaruhi kenyamanan dan kualitas hotel sehingga tamu merasa puas saat menginap di hotel.

Sedangkan persepsi tamu terhadap pelayanan Hotel Naya Gawana Resort and Spa ditinjau dari dimensi harapan menunjukkan kategori sangat setuju. Adapun hasil penelitian di peroleh skor 
dimensi harapan sebesar 2.734 yang berada pada skala interval $2.520-3.000$ yang menunjukkan bahwa persepsi dikategorikan sangat setuju. Hal ini berarti tamu setuju bahwa pelayanan pada saat melaksanakan registrasi untuk tamu dan mengalokasikan kamar sesuai dengan permintaan, tata cara menata kamar/ruangan, dan pelayanan saat menyediakan makanan dan minuman untuk para tamunya sudah dilakukan dengan baik. Disamping itu juga, tamu berpendapat bahwa karyawan hotel sudah berpenampilan rapi dan sopan dalam melayani tamu.

Sedangkan persepsi tamu terhadap pelayanan Hotel Naya Gawana Resort and Spa ditinjau dari dimensi lingkungan menunjukkan kategori sangat setuju. Adapun hasil penelitian di peroleh skor dimensi lingkungan sebesar 4.090 yang berada pada skala interval $3.780-4.500$ yang menunjukkan bahwa persepsi dikategorikan sangat setuju. Hal ini berarti tamu setuju bahwa lokasi hotel sangat mudah ditemukan dan memiliki lingkungan yang bersih yang didukung dengan pemandangan pantai pasir putih di sekitar hotel, dan ruang bangunan hotel yang menarik, sehingga tamu merasa nyaman berada di hotel ini. Disamping itu juga hotel menyediakan tempat ibadah khusus untuk para tamu yang berkunjung ke hotel. Hotel beranggapan bahwa pelayanan sangat penting, karena pelayanan mempengaruhi juga terhadap kepuasan tamu selama berkunjung ke hotel. Pelayanan yang kurang baik terhadap tamu akan menimbulkan tamu enggan untuk berkunjung kembali ke hotel tersebut.

Sedangkan persepsi tamu terhadap pelayanan Hotel Naya Gawana Resort and Spa ditinjau dari dimensi kedekatan menunjukkan kategori sangat setuju. Adapun hasil penelitian di peroleh skor dimensi kedekatan sebesar 2.183 yang berada pada skala interval $2.100-2.500$ yang menunjukkan bahwa persepsi dikategorikan sangat setuju. Hal ini berarti tamu setuju bahwa keluhan yang disampaikan oleh tamu selalu direspon baik oleh karyawan hotel, dan karyawan hotel sudah mampu berkomunikasi dengan baik, komunikasi yang dilakukan karyawan hotel dengan tamu sudah komunikatif dengan tata bahasa yang sudah bagus, sehingga tamu merasa nyaman menginap di hotel ini.

Sedangkan persepsi tamu terhadap pelayanan Hotel Naya Gawana Resort and Spa ditinjau dari dimensi suasana hati menunjukkan kategori sangat setuju. Adapun hasil penelitian di peroleh skor dimensi suasana hati sebesar 1.337 yang berada pada skala interval 1.260 - 1.500 yang menunjukkan bahwa persepsi dikategorikan sangat setuju. Hal ini berarti tamu setuju bahwa pelayanan pada hotel ini sudah memuaskan sehingga tamu sangat senang dan nyaman selama menginap dihotel ini. Di samping itu juga kualitas makanan yang disediakan hotel sudah sesuai dengan harga dan selera tamu hotel. Restaurant yang bersih yang berada disekitaran pinggiran pantai pasir putih memberikan rasa damai dan nyaman untuk para tamu hotel.

Hasil penelitian di atas sesuai hasil penelitian Triana Novian Ginanti yang menyatakan bahwa pentingnya untuk memperhatikan segala persepsi yang diuatarakan oleh para wisatawan, karena melalui sebuah persepsi ini pihak hotel tentunya akan menjadi lebih tahu kekurangan dan kelebihan yang dimiliki serta hal - hal apa saja yang perlu untuk ditingkatkan dan diperbaiki. . Menurut Rakhmat (2007) menyatakan bahwa persepsi adalah pengalaman tentang objek, peristiwa atau hubunganhubungan yang diperoleh dengan menyimpulkan informasi dan menafsirkan pesan. Adapun dimensi persepsi terdiri dari motivasi, harapan, lingkungan, kedekatan dan suasana hati. Hotel Naya Gawana Resort and Spa menawarkan daya tarik wisata baik dari segi motivasi, harapan, lingkungan, kedekatan dan suasana hati dan jasa pendukung pariwisatanya. Selain itu, Hotel Naya Gawana Resort and Spa juga memberikan rasa puas, rasa nyaman, dan rasa aman kepada tamu yang berkunjung. Dengan demikian teori tersebut sesuai dengan hasil penelitian yang menunjukkan bahwa persepsi tamu terhadap pelayanan Hotel Naya Gawana 
Resort and Spa, dimana penelitian secara keseluruhan tamu memberikan tanggapan yang positif terhadap hotel ini. Namun perlu di tingkatkan lagi agar tamu puas, nyaman dan aman dalam berkunjung atau menginap di hotel ini, sehingga tamu senang dan berkunjung kembali.

\section{SIMPULAN DAN SARAN Simpulan}

Berdasarkan hasil penelitian dan pembahasan, maka dapat di simpulkan sebagai berikut, persepsi tamu terhadap pelayanan Hotel Naya Gawana Resort and Spa ditinjau dari dimensi motivasi dikategorikan sangat setuju, bahwa pelayanan hotel kepada tamu sudah memuaskan. Setiap tamu yang datang, karyawan hotel bersedia mengantarkan tamu ke kamar hotel, dan peralatan mandi yang disediakan hotel sudah lengkap dan bersih. persepsi tamu terhadap pelayanan Hotel Naya Gawana Resort and Spa ditinjau dari dimensi harapan dikategorikan sangat setuju, bahwa pelayanan yang diinginkan oleh para tamu sudah sesuai harapan seperti pelayanan pada saat melaksanakan registrasi untuk tamu dan mengalokasikan kamar sesuai dengan permintaan, pelayanan tentang tata cara menata kamar/ruangan, dan pelayanan saat menyediakan makanan dan minuman untuk para tamunya sudah dilakukan dengan baik. Persepsi tamu terhadap pelayanan Hotel Naya Gawana Resort and Spa ditinjau dari dimensi lingkungan dikategorikan sangat setuju, bahwa lokasi hotel sangat mudah ditemukan dan memiliki lingkungan yang bersih yang didukung dengan pemandangan yang indah seperti pantai pasir putih di sekitar hotel, dan penataan ruang bangunan hotel yang menarik, sehingga tamu merasa nyaman berada di hotel ini. Persepsi tamu terhadap pelayanan Hotel Naya Gawana Resort and Spa ditinjau dari dimensi kedekatan dikategorikan sangat setuju, bahwa hotel selalu merespon keluhan para tamu dengan baik. Karyawan hotel sudah mampu berkomunikasi dengan baik, komunikasi yang dilakukan karyawan hotel dengan tamu sudah komunikatif dengan tata bahasa yang sudah bagus. Persepsi tamu terhadap pelayanan Hotel Naya Gawana Resort and Spa ditinjau dari dimensi suasanan hati dikategorikan sangat setuju, bahwa mereka merasakan pelayanan pada hotel ini sudah memuaskan sehingga tamu sangat senang dan nyaman selama menginap dihotel ini. Di samping itu juga kualitas makanan yang disediakan hotel sudah sesuai dengan harga dan selera tamu hotel. Restaurant yang bersih yang berada disekitaran pinggiran pantai pasir putih memberikan rasa damai dan nyaman untuk para tamu hotel.

\section{Saran}

Berdasarkan hasil penelitian yang telah disimpulkan di atas, peneliti dapat memberikan saran sebagai berikut. Pertama bagi pengelola, berdasarkan hasil temuan pada Hotel Naya Gawana Resort and Spa ditinjau dari dimensi motivasi, harapan, lingkungan, kedekatan, dan suasana hati tamu menyatakan sangat setuju bahwa pelayanan pada Hotel Naya Gawana Resort and Spa sudah baik dan memuaskan, sehingga pengelola hotel perlu mempertahankan pelayanan tersebut. Kedua bagi Akademik, bagi peneliti lain yang ingin melakukan penelitian di bidang pariwisata diharapkan mampu menganalisis dan membandingkan pengembangan pariwisata dengan penelitian lainnya untuk memperoleh solusi yang terbaik dalam mengembangkan pariwisata yang ada di Bali atau daerah lainnya. Selain itu penelitian ini perlu di kembangkan dengan referensi lainnya agar penelitian selanjutnya di bidang pariwisata dapat dikembangkan dengan baik.

\section{DAFTAR PUSTAKA}

Hasibuan, Malayu S.P. 2005.Manajemen Sumber Daya Manusia. Jakarta: Bumi Aksara. https://urayiskandar.com/2012/ 09/motivasi-kerja-kepalasekolah.html (20 Desember 2017) 
Irianto, Agus. 2004. Statistik Konsep Dasar dan Aplikasinya. Jakarta: Prenada Media.

Poerwadarminta, W.J.S. 2003. Kamus Umum Bahasa Indonesia. Jakarta: Balai Pustaka.

Rakhmat, Jalaludin. 2006. Psikologi Komunikasi. Bandung: Remaja Rosdakarya.
---------------- $2007 . \quad$ Psikologi Komunikasi. Edisi Revisi. Bandung: Remaja Rosdakarya.

Robbins, S.P \& Judge. ThimothyA.. 2009. Perilaku Organisasi. Buku 1. Jakarta: Salemba Empat.

Sarwono, Sarlito. 2002. Pengantar Psikologi Umum. Jakarta: Rajawali Press.

Siagian, Sondang P. 1986. Manajemen Sumber Daya Manusia. Jakarta: Bumi Aksara. http://triwidodowutomo.blogspot.c om/2010/10/perilaku-organisasi3-motivasi.html?m=1 (20 Desember 2017)

Slameto. 2003. Belajar dan Faktor - faktor yang Mempengaruhinya. Jakarta: Rineka Cipta.

Sulastiyono, Agus. 2002. Manajemen Penyelenggaraan Hotel. Bandung: Alfabeta.

Walgito, Bimo. 2002. Pengantar Psikologi Umum. Yogyakarta: Andi Offset. 2004. Pengantar Psikologi Umum. Edisi IV. Yogyakarta: Andi Offset. 